\title{
Conceptual design of a 20 TBP port tugboat for the "Bahía Málaga" ARC Naval Base
}

Diseño conceptual de una embarcación tipo remolcador de puerto de 20 TBP para la Base Naval ARC "Bahía Málaga"

DOI: https://doi.org/10.25043/19098642.178

Orlando Royet del Gallego ${ }^{1}$

Diego Orozco Howard ${ }^{2}$

\begin{abstract}
This work is part of the development of a conceptual proposal for a 20-ton bollard pull harbor tug, for the support of vessels no greater than 7,500 tons of displacement with safety standards for port maneuvers within the jurisdictional areas of the Colombian maritime authority (DIMAR) for the Colombian Navy. The design of this vessel was focused in providing the best opportunities to take into account, because the Colombian Navy fleet will have new vessels with greater displacement by the year 2030, this growth will be require the acquisition of new tugs. The execution of this design was based on the regulation of the "American Bureau of Shipping", abbreviated ABS, complying with all the specifications and parameters of a harbor tug. The Colombian Navy units of this type are currently boats whose useful life is over 5 years, which entails unsafe maneuvering, risking human lives and the units themselves. Currently, the Navy requires new towing services to comply with its institutional mission. This project seeks to develop a conceptual design for future projects to undertake the construction of this vessel. In this way, we will be fulfill the development objectives of the Strategic Surface Force the Faro 2030 Plan.
\end{abstract}

Key words: Bollard pull, autonomy, advance Resistance, Van Oortmerssen.

\section{Resumen}

El presente trabajo se enmarca en el desarrollo de una propuesta conceptual para un remolcador de puerto de 20ton de bollard pull, propuesto para realizar sus operaciones en bahía, para el apoyo de embarcaciones no mayores a 7500 toneladas de desplazamiento manteniendo las normas de seguridad para maniobras dentro de las áreas jurisdiccionales de la autoridad marítima (DIMAR). El diseño de esta embarcación fue enfocado con el fin suplir las necesidades futuras teniendo presente que la flota naval colombiana para el ańo 2030 tendrá un gran número de buques, este crecimiento obliga a la adquisición de nuevos remolcadores. La realización de este diseño se basa en el reglamento de la casa clasificadora "American Bureau of Shipping", abreviado ABS, cumpliendo con todas las especificaciones características y parámetros de un remolcador de puerto. Las unidades colombianas de este tipo actualmente son embarcaciones que su tiempo de vida útil puede haber pasado más 5 años, lo que conlleva a tener maniobras inseguras, arriesgando vidas humanas y las propias unidades. Actualmente la Armada Nacional requiere nuevas embarcaciones de remolcadores apropiados para cumplir con la misión institucional buscando también el aporte a la protección del medio ambiente. Este proyecto busca iniciar con un diseño conceptual con el fin de que proyectos futuros lleguen a la construcción de esta embarcación, de esta manera se cumpliría uno de los objetivos para el desarrollo de la Fuerza Estratégica de Superficie plan Faro 2030.

Palabras claves: Tracción punto fijo, resistencia al avance, Van Oortmerssen.

Date Received: November $18^{\text {th }} 2018$ - Fecha de recepción: Noviembre 18 de 2018

Date Accepted: January $6^{\text {th }} 2019$ - Fecha de aceptación: Enero 6 de 2019

\footnotetext{
${ }^{1}$ Escuela Naval de Cadetes "Almirante Padilla”. Cartagena, Colombia. Email: orlando.royet@armada.mil.co

${ }^{2}$ Escuela Naval de Cadetes "Almirante Padilla”. Cartagena, Colombia. Email: diego.orozco.ho@armada.mil.co
} 


\section{Introduction}

This project seeks to carry out the conceptual design of a port towing unit to provide assistance to the sailing, mooring, and movement maneuvers of vessels in waters restricted by the channel. The main objective is to study the design of a bay tug with a capacity of 20TBP (Ton Bollard Pull), in order to acquire it for the Pacific Naval Base (BN2), considering that at the moment, the Pacific Naval Force does not have a tug type unit.

\section{Work Objectives}

\section{General objective}

Carry out the conceptual design of a tugboat with a capacity of 20TBP (Ton Bollard Pull) for the Bahía Málaga Naval Base, in order to assist the maneuvers of the surface units.

\section{Specific objectives}

1. Prepare the mission profile study, based on the requirements of the National Navy and define its main dimensions.

2. Conduct research on port tugs with a 20 TBP capacity.

3. Design the shape lines as the basis for preliminary stability, maneuverability and intact stability calculations in order to determine the buoyancy of the tugboat.

4. Estimate the ship's forward resistance and determine the power required in the propulsion system.

\section{Methodology}

The work methodology will be through the use of the design spiral, which is cyclic and iterative, and seeks to establish and develop the concepts proposed in each phase of the project considering that these concepts have a direct relationship between them, therefore all considerations must be taken into account to define a concept, constantly reviewing the concepts in order to achieve a result that adapts to the characteristics experienced by the design spiral. Applying it in all the phases of the project, requires the development to be carried out point by point and relating to each one to reach its center or detailed design phase.

From the data, the tasks are developed sequentially and when the first round of the design spiral is completed, it can be said that the vessel has been defined at its preliminary design level. Every time the spiral goes through its completion of a new cycle, the corresponding task is deepened in its definition.

Within the design spiral (Fig. 1), the conceptual design of a 20TBP tug for the Malaga Bay Naval Base will be developed, comprising 8 booklets where each one will contribute to the final objective of delivering the "Ship Project" design listed in the following table:

Table 1. List of booklets for "Ship Project" design

\begin{tabular}{|c|c|}
\hline Booklet & Specifications \\
\hline 1 & Concept exploration \\
\hline 2 & Mission Profile study \\
\hline 3 & Dimensioning \\
\hline 4 & Naval architecture calculations \\
\hline 5 & Systems Dimensioning \\
\hline 6 & Electrical Balance \\
\hline 7 & Capacities and stability \\
\hline 8 & Cost \\
\hline
\end{tabular}

\section{Mission profile}

Its main function will be to tow and support the maneuvers of vessels that arrive, depart, change dock, transit through the channel, maneuvers restricted to vessels that require the assistance of the tugboat. This vessel has a bullard pull of 20 ton for a maximum operating capacity of 7500 tons deadweight.

The mode of operation will be dedicated to towing and assisting maneuvers since they will be its main functions for which the port towing vessel will be designed.

It will have an annual operation of 2304 hours with the following operation profile: 
Fig. 1. Design Spiral, by (Gonzalez, 2011)

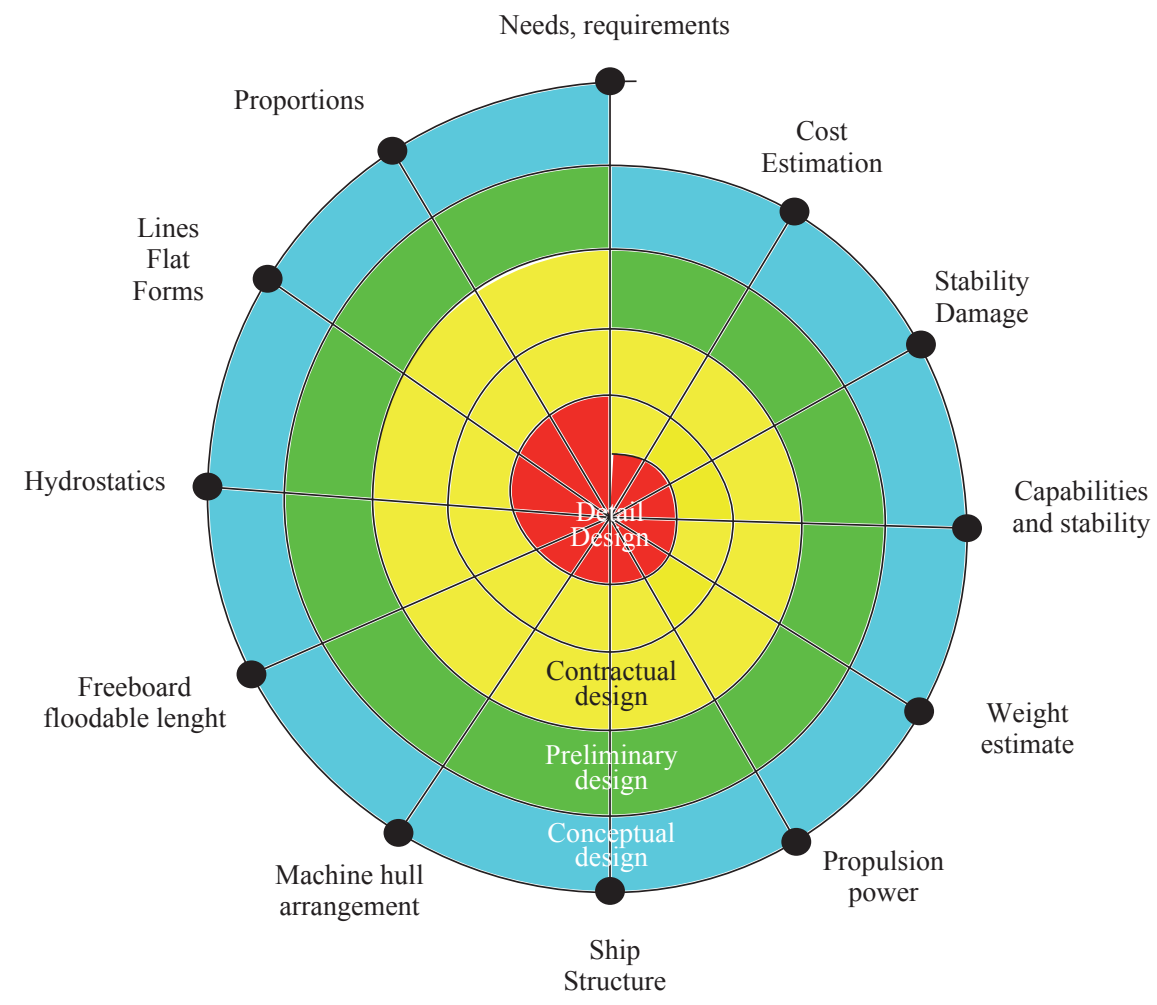

Speed from 0 to 6 knots

Cruise speed from 6 to 10 knots

Maximum speed of 11 knots

In order to determine the main dimensions of the design, it was necessary to compile a database of existing vessels through different means of information from which information was obtained from ten (10) vessels shown in the following data table:

Table 2. Dimensions and general characteristics

\begin{tabular}{|c|c|c|}
\hline \multicolumn{3}{|c|}{ General dimensions and Characteristics } \\
\hline Length & 17 & [Meters] \\
\hline Beam & 7 & [Meters] \\
\hline Height & 3,4 & [Meters] \\
\hline Depth & 2,3 & [Meters] \\
\hline Displacement & 162 & {$[$ Ton] } \\
\hline Speed & 11 & {$[\mathrm{Kn}]$} \\
\hline Autonomy & 15 & {$[$ Days $]$} \\
\hline Crew & 4 & [Persons] \\
\hline
\end{tabular}

$60 \%$.

$10 \%$
30\%. Shape lines

The definition of the ship shapes is of great importance in the design. From these shapes it the storage and handling needs of the cargo are verified. The speed is also checked through different procedures in the test channels or through the maxsurf software.

The shapes of the tug project are conditioned by the activity carried out by the vessel. Although it is qualified as a cargo ship by the Classification Society Guidelines, it is a ship that provides a service, so the cargo will not be decisive in the choice of its forms, but due to its design and function, the ship resistance must be reduced as much as possible.

According to the specification, the project vessel is a conventional type tug that will perform assistance and support functions, which is decisive in the choice of design. 
Fig. 2. Hull shapes

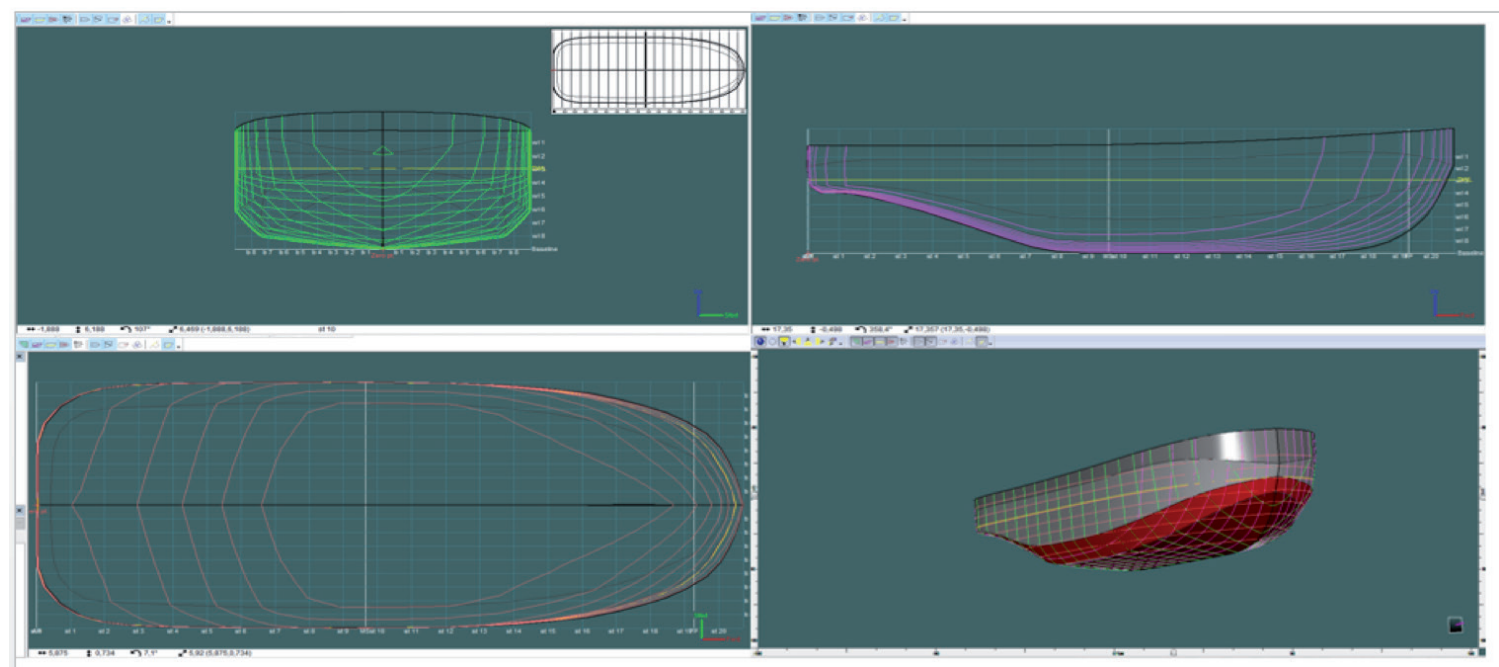

\section{Advance resistance}

Different methods of analysis are available to determine the ship resistance of a vessel.

a. Experimental methods: These are the processes traditionally used in model trials. This procedure is often expensive and slow, so it is often used in the final stages of the project to validate the expectations of the project.

b. Statistical methods: These methods are based on regression analysis on model tests and measurements of real ships.

c. Finally, numerical methods. This is the method we have used for resistance analysis and power prediction.

These processes are performed through computer simulation tools. One of the main advantages of using these tools is that it allows you to evaluate the possible modifications in the shapes at any time.

The Van Oortmerssen method was determined for this project, since it has much more correlation for this type of tugs, being an algorithm designed to predict the advance resistance focused on small cargo vessels, fishing vessels and tugs, (Arbuniéz \& Caja, 2015, p. 34).

The analysis shows that for a speed of $11 \mathrm{Kn}$ there is a total resistance of $117.1 \mathrm{KN}$ and an estimated power of $1124.373 \mathrm{KW}$ which are the starting point for power prediction.

\section{Powering}

Based on the data obtained, referring to the advance resistance and calculation of the optimum propeller for the vessel being designed, the vessel in the project will have two axle lines with one power in each engine:

\section{BHP: $592 \mathrm{KW}$}

Table 3. Engine Comparison

\begin{tabular}{|c|c|c|c|c|c|c|}
\hline Name & \multicolumn{2}{|c|}{ CAT } & \multicolumn{2}{|c|}{$\begin{array}{l}\text { MTU 12V } \\
2000 \text { M61 }\end{array}$} & \multicolumn{2}{|c|}{$\begin{array}{l}\text { MAN } \\
\text { D2862 }\end{array}$} \\
\hline Power & & $50 \mathrm{HP}$ & & 805HP & & $749 \mathrm{HP}$ \\
\hline Rated speed & 1800 & RPM & 1800 & 0 RPM & 180 & 0 RPM \\
\hline $\begin{array}{l}\text { Cylinders } \\
\text { number }\end{array}$ & & $12 \mathrm{~V}$ & & $12 \mathrm{~V}$ & & $12 \mathrm{~V}$ \\
\hline $\begin{array}{l}\text { Specific fuel } \\
\text { consumption }\end{array}$ & 205,3 & $\frac{g}{K W h}$ & 215 & $\frac{g}{K W h}$ & 213 & $\frac{g}{K W h}$ \\
\hline $\begin{array}{l}\text { Consumption } \\
\mathrm{g} / \mathrm{h}\end{array}$ & & 41,0 & & 34.1 & & 38 \\
\hline $\begin{array}{l}\text { Dimensions } \\
\mathrm{mm}\end{array}$ & $1931 \times$ & $\begin{array}{l}x 1300 \\
x 1204\end{array}$ & & $\begin{array}{r}1890 \mathrm{x} \\
1400 \mathrm{x} \\
1290\end{array}$ & & $\begin{array}{r}2130 x \\
1153 x \\
1230\end{array}$ \\
\hline
\end{tabular}


The selected engine is a Diesel MTU 12V-M61, which compared to the other engines observed in the table has a fuel consumption $\mathrm{g} / \mathrm{h}$ which equals a better performance, and the dimensions show that it is smaller than the other two engines shown in the data table. The engine is from the German company MTU with a power of $1184 \mathrm{Kw}$ equivalent to $1610 \mathrm{HP}$.

Fig. 3. Marine engine MTU 12V2000M61

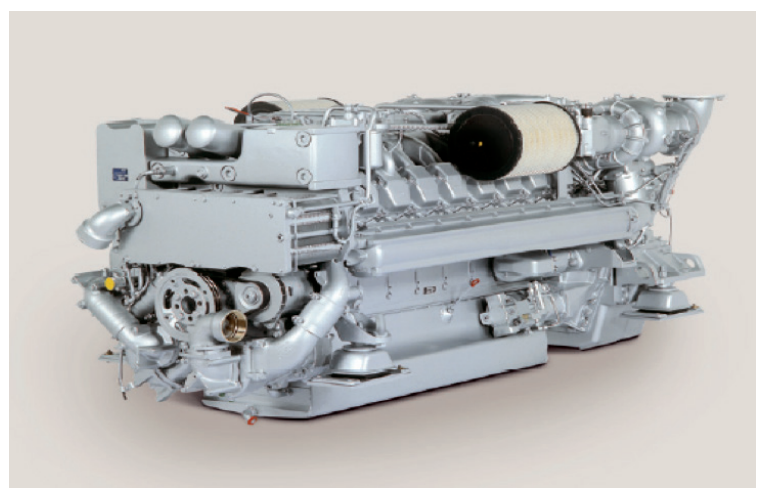

According to the chosen engine manual, by recommendation it is compatible with the ZF 5000 NR2H gearbox with a 2.963 ratio, which does not require a special manufacturing order.

Fig. 4. Transmission ZF 5000 NR2H

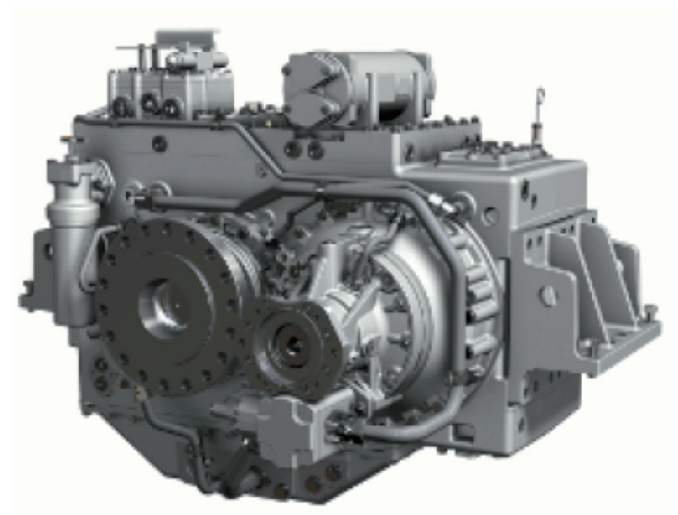

The design of this vessel requires that the propulsion system has a 4-blade propeller. To avoid torsional vibrations and synchronisms induced by axial thrust of the blades, kort type nozzles are implemented for each propeller, which decreases the vibration induced in the hull by the propeller, since it provides a greater regularity of the flow inside, reducing the fluctuations generated by the propulsion engine. It also provides protection to the flow of water affected by the propeller and therefore decreases pressure variations on the hull around the propeller. These nozzles are designed to increase the traction force of the tug at low speeds.

Table 4. Propeller characteristics

\begin{tabular}{lrr}
\hline \multicolumn{1}{c}{ Helix } & \\
\hline Diameter (inches) & & 67,29 \\
\hline Pitch (inches) & & 48,44 \\
\hline$Z$ & 4 \\
\hline$P / d$ & 0,7 \\
\hline
\end{tabular}

\section{Command and Surveillance}

The tug must have the following navigation and communications equipment GMDSS A1 (Global Maritime Distress and Safety System) is a SOLAS and IMO convention, an international agreement on safety procedures, types of equipment and communications protocol to enhance maritime safety, divided into 4 maritime zones. The ship design will use zone a1 which is between $20-30$ MN from the coast.

- $\quad$ TR-20

- An MF/HF transmitter-receiver with double PR-300 feeder equipped with DSC-6A equipment for MF selective call control.

- Two VHF transmitter-receiver devices with DSC equipment and extensions to cabins, dining room.

- One Tron TR-20 portable radiophone

- One Navtex NX-500 receiver

- One $406 \mathrm{MHz}$ EPIRB radio beacon

- One $9 \mathrm{GHz}$ radar transponder

- One high-resolution radar

- GPS receiver with LCD plotter

- Gyroscopic with interface for autopilot, repeaters and navigation equipment

- Master logbook with backup compass and alidades to mount on the compass

- Graphic and digital Echo sounder with LCD screen

- One anemometer with sensors on indicators 
- For indoor communications, command telegraph equipment shall be mounted on a transmitter and two receivers, a maneuvering loudspeaker system with 2 repeaters on the main deck and the bridge.

\section{Auxiliary Systems}

The tugboat will need the basics for its operation and therefore the following auxiliary equipment must be installed:

- Two starting air compressors from $14 \mathrm{~m} 3 / \mathrm{h}$ to 30 bar.

- One emergency starting air compressor from 9 $\mathrm{m}^{3} / \mathrm{h}$ to $30 \mathrm{bar}$

- Pressurized air dryer filters

- One petrol purifier with a capacity of $1500 \mathrm{l} / \mathrm{h}$

- One electric centrifugal pump of $40 \mathrm{~m}^{3} / \mathrm{h}$ at 3 bar for fresh cooling water service, as backup for the main engine.

- Two centrifugal electric pumps of $70 \mathrm{~m}^{3} / \mathrm{h}$ at $3 \mathrm{bar}$, for the salt water pump of the main engine.

- One electric centrifugal pump of $15 \mathrm{~m}^{3} / \mathrm{h}$ at $3 \mathrm{bar}$, for transferring fresh water within the ship.

- Two centrifugal electric pumps of $25 \mathrm{~m}^{3} / \mathrm{h}$ at $4 \mathrm{bar}$ and $40 \mathrm{~m}^{3} / \mathrm{ha} 1,5 \mathrm{bar}$, for flushing, firefighting, ballast and bilge pumping.

- One electric helical pump of $5 \mathrm{~m}^{3} / \mathrm{h}$ at $1,5 \mathrm{bar}$, for oily waters.

- One self-suction electric pump with a $15 \mathrm{~m}^{3} / \mathrm{h}$ screw at $2 \mathrm{bar}$, for fuel transfer.

- One $2.5 \mathrm{~m}^{3} / \mathrm{h}$ at 5 bar self-suction screw electric pump for the main engine fuel reserve service.

- One $35 \mathrm{~m}^{3} / \mathrm{h}$ at 10 bar self-suction screw electric pump for the main engine reserve oil lubrication service.

- One electric centrifugal pump of $1 \mathrm{~m}^{3} / \mathrm{h}$ at 2 bar, for waste water discharge.

- One electric centrifugal pump of $20 \mathrm{~m}^{3} / \mathrm{h}$ at 2,5 bar, for salt water cooling of the air conditioning equipment.

- One salt water hydrophore, consisting of a pump of $2 \mathrm{~m}^{3} / \mathrm{h}$ at $3 \mathrm{bar}$, with a $50 \mathrm{l}$ capacity tank.
- One fresh water hydrophore composed of a pump of $4 \mathrm{~m}^{3} / \mathrm{h}$ at 3 bar, with a 50 l. capacity tank.

- One bilge separator with a $1 \mathrm{~m} 3 / \mathrm{h}$ capacity.

- One biological waste water treatment plant, which receives by gravity and treats waste water for 4 people on board.

- Two axial and reversible fans with a flow of $25000 \mathrm{~m} 3 / \mathrm{h}$ each, for the ventilation of the machine room.

- One centrifugal fan with a capacity of 2000 $\mathrm{m}^{3} / \mathrm{h}$ for the engine service room.

\section{Outfit and Furnishings}

The ship shall have enough space to accommodate a crew of 4 persons consisting of:

- Under the main deck two double cabins equipped with bunk beds, wardrobe and desk, bathroom with shower, toilet and washbasin, washing machine and dryer for crew, living room for 4 people, stainless steel kitchen, food pantry room, with a freezer inside, a longitudinal corridor from stern to bow will connect the engine room with a hatch entrance and exit, then with cabins on each side, along the corridor there will be communication with the bridge on the main deck that will have a hatch to exit the bridge, interior doors will be galvanized steel with PVC or stainless steel, acoustic insulation and thermal insulation for high noise reduction and fire resistant.

\section{Structural Design}

The structural study of a ship can be carried out by considering it as a beam ship in which the shear and flexural stress to which the ship is subjected in a specific condition are studied, for the calculation of these stresses the most drastic conditions must be taken into account.

The American Bureau of Shipping (ABS), part 3 , guide for building and classing will be used for the analysis. 
For this project, which is defined as a Conceptual Design, a breakdown will be made of the main structural elements of the vessel "20 TBP Port Tug for the National Navy", the frames, web frames, longitudinal and transverse bulkheads. Vessels of this type have mainly, a transverse structure with special reinforcements in the keel area, the propellers and especially in the bulwark, an area that can be especially subject to blows during operations.

\section{Estimate of electricity generation system}

In order to carry out the electrical balance, the loading conditions in port, navigation, maneuvering and emergency have been studied. From this study, the power in KW required for the power plant was obtained. This consists of two main Caterpillar generators, model C4.4 of the following technical characteristics: 100kW, 125 kVA, 220VAC, 320Amp, power factor 0.8, 1800 RPM and an emergency Caterpillar generator
Table 5. Selected reinforcements

\begin{tabular}{lr}
\hline \multicolumn{1}{c}{ Thicknesses } & \\
\hline Depth, double depth, central rail & $6,25 \mathrm{~mm}$ \\
\hline Bar keel & $12,82 \mathrm{~mm}$ \\
\hline Rod & $11,25 \mathrm{~mm}$ \\
\hline Codaste & $22 \mathrm{~mm}$ \\
\hline Side Girder & $5,3 \mathrm{~mm}$ \\
\hline floor & $6,8 \mathrm{~mm}$ \\
\hline Double bottom roof & $7,13 \mathrm{~mm}$ \\
\hline Bottom plating & $6,129 \mathrm{~mm}$ \\
\hline Bottom beams (stern) & $14 \mathrm{~mm}$ \\
\hline Watertight bulkheads & $7,04 \mathrm{~mm}$ \\
\hline Machine room bulkheads & $6,6 \mathrm{~mm}$ \\
\hline Collision bulkhead & $9,25 \mathrm{~mm}$ \\
\hline Side plate & $7,5 \mathrm{~mm}$ \\
\hline Cover thickness
\end{tabular}

C4.4 Model ACERT 4.4 three phase, 36kW, $120 \mathrm{~V}$ 240V, $60 \mathrm{HZ}, 1800 \mathrm{rpm}$. The main generators will be located in the machine room on both sides, connected to the main board. The emergency

Fig. 5. Master binding

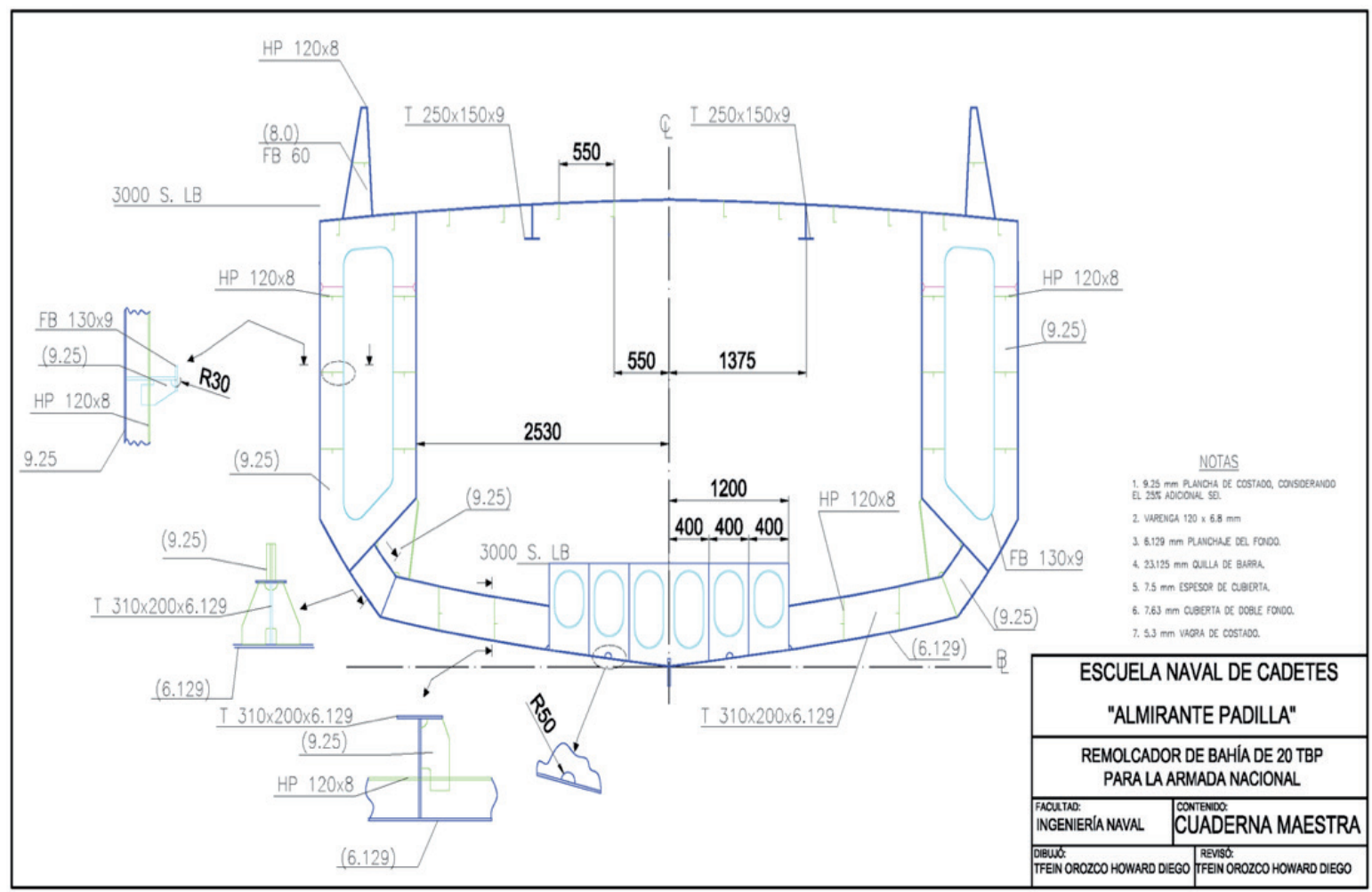


engine generator will be located in a separate compartment for that system only.

The diesel engine of the emergency generator will be started by means of an electric engine and battery, connected by means of a low voltage contactor to the emergency bars in the panel.

\section{Cost Estimate}

The cost estimate for this tugboat design was made in a general way, in order to obtain a conceptual estimate of the costs for construction. The calculation of estimated costs is calculated without considering the "other" expenses that may result, where only the hull, structure, material, costs of shipyard, equipment, machinery and facilities were estimated.

For the estimation calculations the approximation established by (Carreyette, 1977, $p$ 245) is used, in which you can estimate the price of a ship, considering the following characteristics for a tugboat:

Table 6. Characteristics of the 20 PBS tugboat

\begin{tabular}{|c|c|c|}
\hline \multicolumn{3}{|c|}{ Main Characteristics } \\
\hline Flotation Length (Lw) & 16,32 & $\mathrm{~m}$ \\
\hline Beam (B) & 7 & $\mathrm{~m}$ \\
\hline Prop (D) & 3,4 & $\mathrm{~m}$ \\
\hline Draft $(\mathrm{T})$ & 2,3 & $\mathrm{~m}$ \\
\hline Displacement (A) & 162 & $\operatorname{Tn}$ \\
\hline Threaded Weight & 122 & $\operatorname{Tn}$ \\
\hline Dead Weight & 40 & $\operatorname{Tn}$ \\
\hline Block Coefficient (Cb) & 0,586 & \\
\hline Crew & 4 & Persons \\
\hline Propeller Power & 1543 & Php \\
\hline
\end{tabular}

Finally, an estimation of the shipyard costs is made, which includes services, materials, tools, equipment, machinery, among other elements. Also, the estimation of the general expenses is made, which are included and are characterized by carrying a $\%$ of expense similar to $30 \%$ of total cost in man hours. It is also estimated that the construction profit is $5 \%$.
Table 7. Estimation of the total cost of the vessel

\begin{tabular}{|c|c|}
\hline \multicolumn{2}{|c|}{ Estimated total cost of vessel construction } \\
\hline Total cost of steel and profiles & $\$ 507^{\prime} 960.000$ \\
\hline Total cost of welding & $\$ 76^{\prime} 194.000$ \\
\hline Total cost for man hours & $\$ 82^{\prime} 170.000$ \\
\hline $\begin{array}{l}\text { Total cost of machinery, equipment } \\
\text { and systems }\end{array}$ & $\$ 1.141^{\prime} 000.000$ \\
\hline Total cost of shipyards and other & $\$ 180^{\prime} 000.000$ \\
\hline Total general cost & $\$ 24^{\prime} 651.000$ \\
\hline Estimated total cost & $\$ 2.011^{\prime} 975.000$ \\
\hline
\end{tabular}

In principle, the estimated cost of building the port tugboat would be $\$ 2,011^{\prime} 975,000$ Colombian pesos.

\section{Conclusions}

In this investigation, the proposed objectives were met.

A conceptual design was achieved, fulfilling each of the proposed objectives, concerning port tugboat for the National Navy, having the necessary capabilities to support the vessels of the entire naval fleet. It is of great importance that the design of a vessel of this type can be developed into its construction, considering the institutional plan of the National Navy of compliance, plan 2030 .

The design and context of this project is achieved with the help of computer tools, being able to design the hull shapes in the Maxsurf software, maintaining the main characteristics, determining a reliable analysis. It was also possible to analyze and evaluate the type of propulsion, propellers and generators to be selected.

For the propulsion system, the installation of two 1610hp MTU propellers, two lines of axles with 4 blades propeller, a diameter of 67.29in, were considered, thus meeting the power requirement to overcome the advance resistance of these vessels.

The design focused on the calculation of the advance resistance, and weight capacities, all analyzed and determined with the computational tools. 
Finally, an approximate cost estimate was determined, considering the conceptual analysis up to its construction and launching, analyzing each possible cost, dividing the construction by construction groups and taking an organization with reference in the design and construction methodology. The total cost estimate for this tugboat was $\$ 2.011^{\prime} 975.000$ projected for construction in 2020 .

To carry out the development of this project requires great knowledge in computational tools focused on design and engineering analysis, focused on the naval issue. In addition, it must have a permanent company of teachers, naval engineers and the shipyard's own engineers, in this case, Cotecmar.

\section{References}

ABS. (02 de 2012). ABS. American Bureau of Shopping. Houston, USA.

ACEVES ESCUDERO, J. (2010). Remolcador Tractor de Puerto de 30T. Escuela Técnica Superior de Ingenieros Navales.

ALVARIÑO CASTRO, AZPÍROZ AZPÍROZ, MEIZOSO FERNÁNDE, R. (1997). EL PROYECTO BÁSICO DEL BUQUE MERCANTE. Madrid: Fondo Editorial de Ingenería Naval Colegio oficial de Ingenieros Naveles.

ARMADA NACIONAL. (29 de Abril de 2005). Resolucion de DIMAR para Remolcadores. Colombia.

ARMON. (24 de Dieciembre de 2017). Obtenido de buque polivalente de salvamento marítimo LUZ DE MAR IIM 9320104: https:// cx9aaw.wordpress.com/2017/12/24/buquepolivalente-de-salvamento-maritimo-luz-demar-imo-9320104/

BAQUERO MAYOR, A. (01 de 2011). Propulsión del Buque.
BARBUDO. (1993). Conocimientos Marineros. HEROICA ESCUELA NAVAL.

BESELGA RODRÍGUE, M. (1981). El remolque en el mar o remolque de transporte Ira Edición. Sevilla: Artes graficas salesianas.

CASADO, I. S. (julio de 2010). Remolcador de altura. Cádiz, España.

CHERUBINO NICOLÁS, G. J. (Julio de 2010). Introducción a la Ingenería Naval. Argentina, Buenos Aires.

Courtesy of Sanmar A.S. (s.f.). Obtenido de VectRA 3000 series Tugs: https://www.shiptechnology.com/projects/vectra-3000-seriestugs/attachment/vectra-3000-series-tugs1/

DAMEN. (Septiembre de 2015). Obtenido de Stan Tug 4013: https://products.damen.com/en/ ranges/stan-tug/stan-tug-4013

DAMEN. (Mayo de 2017). Obtenido de Stan Tug 1907 Ice Claass3: https://products.damen. com/en/ranges/stan-tug/stan-tug-1907-iceclass

DAMEN. (Holanda). ASD TUG 5114. Obtenido de https://products.damen.com/en/ranges/asdtug/asd-tug-5114

DAMEN Shipyards Group. (2018). Obtenido de Remolcadores de Puerto: https://products. damen.com/es-es/clusters/harbour-tugs

DIMAR. (s.f.). Obtenido de DIMAR, MAPS: http://dimar.maps.arcgis.com/apps/ webappviewer/index.html?id=59e44745 ca034 8658f8a049d81892933

DIMAR . (16 de 12 de 2004). Resolucion 0417. Colombia. edit.MARINO. (s.f.). Remolcadores Parte 5.

ESCOBAR GARCIA, N. (2017). Obtenido de El oro no siempre es dorado: bahía málaga, estrategias de turistificación en el pacífico 
colombiano: http://ecomanglar.org/wpcontent/uploads/2013/06/Mapa-4-AreasProtegidas.jpg

EYRES, G. J. (12 de Mayo de 2012). Obtenido de Ship Construction: https://es.scribd.com/ book/282546201/Ship-Construction

FERRI, Talleres CARRAL. (s.f.). FERRI. Obtenido de industria Ferri S.A.: http://ferrisa.es/es/otros/

GARCÍA, C. P. (2017). Buenaventura, Cartagena, Santa Marta y Barranquilla, los puertos claves del comercio exterior Colombia. Revista de Logística, 01 .

GARCIA, R. (22 de Noviembre de 2012). Ingeniero Marino. Artículo. Revista ingeniero naval.

GERR, D. (2001). Propeller Handbook. Maine, Camden: International Marine.

GOMEZ, A. O. (Octubre de 2012). Remolcadores y Actualizaciones de Salvamento Maritimo. Cantabria, España.

ITES-PARANINFO. (s.f.). SCRIBD. Obtenido de equipo de amarre y fondeo: https://es.scribd. com/doc/271405198/Equipo-de-Amarre-yFondeo

JARAMILLO, J. (27 de enero de 2011). http:// historia-maritima.blogspot.com. Obtenido de http://historia-maritima.blogspot.com.

LARA, M. P. (julio de 2009). Anteproyecto de remolcador de altura de 35 T.P.F. Cádiz, España.

LARA, M. P. (Julio de 2009). Remolcador de altura 35 T.P.F. Ingeniero Técnico Naval Estructura MArina. Cádiz, España: Universidad de Cádiz.

LARSSON, L., \& RAVEN, H. C. (2010). Ship Resistance and Flow (1a edición ed.). (R. P. J, Ed.) New Jersey, New Jersey, Estados Unidos:
The Society of Naval Architects and Marine Engineers.

LEMOS, E. E. (2011). modificación de un remolcador de altura para brindar servicios de remolque portuario en la ciudad de puerto bolivar. Guayaquil, Ecuador.

MEDINA GUERRA, A. (05 de 2016). Sistema de reducción de la resistencia. Barcelona.

MTU. (s.f.). Diesel Engine 12V 2000 M61. Friedrichshafen, Germany.

NAUTICEXPO. (2018). Obtenido de Virtual Expo: http://www.nauticexpo.es/prod/ posidonia-srl/product-33212-239217.html

REMOLCADORES. (s.f.). Diagrama de empuje para sistema de propulsión.

ROBERT ALLAN LTD. (s.f.). Obtenido de RAVE SERIES 2900: http://ral.ca/series/rave/

ROBERT ALLAN LTD. (s.f.). Obtenido de Naval Architects and marine Engineers: http://ral.ca/ series/rave/

TF JIMENEZ NOHORA, T. P. (2016). Proyecto buque. Diseño conceptual de un buque tipo CPV para operaciones de interdicción maritima en el pacífico colombiano. Cartagena, Bolivar, Colombia.

TTS MARINE. (s.f.). Nauti Expo. Obtenido de http://www.nauticexpo.es/prod/tts-marine/ product-31735-277143.html

ZF FRIEDRICHSHAFEN. (2017). Obtenido de Marine ZF: https:/marine.zf.com/matran/\#!/ dataSheet/542

ZHENJIANG NORMAN IMPORT Y EXPORT CO LTDA. (02 de febrero de 2010). Marine boat Bronze Flap Rudder. Obtenido de https:// norman0607.en.made-in-china.com/product/ gbIxLwRoLCcO/China-Marine-Boat-BronzeFlap-Rudder-for-Sale.html 